\title{
Article
}

\section{The Cytotoxic effect of an Ethanol extract of Momordica Charantia, Kuguacin-J and Cisplatin on healthy MCF-10A and MCF-7 and MDAMB-231 breast cancer cell lines employing In Vitro assays}

Houacine, Chahinez, Singh, Jaipaul, Singh, Raphael, Jeeboo, Karishma, Ansari, Abdullah Adil, Singh, Kamalinder and Cummings, Emanuel

Available at http://clok.uclan.ac.uk/38705/

Houacine, Chahinez, Singh, Jaipaul ORCID: 0000-0002-3200-3949, Singh, Raphael, Jeeboo, Karishma, Ansari, Abdullah Adil, Singh, Kamalinder ORCID: 0000-0001-7325-0711 and Cummings, Emanuel (2021) The Cytotoxic effect of an Ethanol extract of Momordica Charantia, Kuguacin-J and Cisplatin on healthy MCF-10A and MCF-7 and MDAMB-231 breast cancer cell lines employing In Vitro assays. The Gazette of Medical Sciences, 2 (4). 016-029. ISSN 2692-4374

It is advisable to refer to the publisher's version if you intend to cite from the work. /10.46766/thegms

For more information about UCLan's research in this area go to http://www.uclan.ac.uk/researchgroups/ and search for <name of research Group>.

For information about Research generally at UCLan please go to http://www.uclan.ac.uk/research/

All outputs in CLoK are protected by Intellectual Property Rights law, including Copyright law. Copyright, IPR and Moral Rights for the works on this site are retained by the individual authors and/or other copyright owners. Terms and conditions for use of this material are defined in the policies page. 


\section{The Cytotoxic effect of an Ethanol extract of Momordica Charantia, Kuguacin-J and Cisplatin on healthy MCF-10A and MCF-7 and MDAMB-231 breast cancer cell lines employing In Vitro assays}

\author{
Chahinez Houacine $^{1^{\star}}$, Jaipaul Singh ${ }^{2}$, Raphael Singh ${ }^{1,2}$, Karishma \\ Jeeboo $^{3}$, Abdullah Adil Ansari ${ }^{4}$, Kamalinder K Singh', Emanuel \\ Cummings ${ }^{2,3}$
}

${ }^{1}$ School of Pharmacy and Biomedical Sciences, Faculty of Clinical and Biomedical Sciences, University of Central Lancashire, Preston PR1 2HE, UK

(Chouacine1@uclan.ac.uk/Chahinez.houacine1@gmail.com; Ksingh1@uclan. ac.uk)

${ }^{2}$ School of Natural Sciences, Faculty of Science and Technology, University of Central Lancashire, Preston England, PR1 2HE, England, UK (Jsingh3@uclan.ac.uk). ${ }^{3}$ Schools of Medicine and Pharmacy, College of Medical Sciences, University of Guyana, Georgetown, Guyana (Emanuel.cummings@uog.edu.gy;

(Kjeeboo@uog.edu.gy)

${ }^{4}$ Departments of Biology and Chemistry, Faculty of Natural Sciences, University of Guyana, Georgetown, Guyana (Abdulah.ansari@uog.edu.gy);

(raphael_singh@yahoo.com)
Submitted: 28 June 2021

Approved: 19 July 2021

Published: 20 July 2021

Address for correspondence:

Dr Chahinez Houacine, PhD, School of Pharmacy and Biomedical Sciences, University of Central Lancashire, Preston, PR1 2HE, United Kingdom.

How to cite this article: Houacine C, Singh J, Singh R, Jeeboo K, Ansari AA, et al. The Cytotoxic effect of an Ethanol extract of Momordica Charantia, Kuguacin-J and Cisplatin on healthy MCF-10A and MCF-7 and MDAMB-231 breast cancer cell lines employing In Vitro assays. G Med Sci. 2021; 2(4): 016-029.

https://www.doi.org/10.46766/thegms.pharma.21062806

Copyright: (c) 2021 Chahinez Houacine, Jaipaul Singh, Raphael Singh, Karishma Jeeboo, Abdullah Adil Ansari, Kamalinder K Singh, Emanuel Cummings. This is an Open Access article distributed under the Creative Commons Attribution License, which permits unrestricted use, distribution, and reproduction in any medium, provided the original work is properly cited.

\begin{abstract}
Traditional medicines, derived from plants, could present alternative treatment strategy for cancer therapy. One such plant is Momordica charantia (MC) which possesses anti-carcinogenic properties. This study investigated the anticancer effect of an ethanol extract of MC fruit, Kuguacin-J (K-J), an isolated compound from the leaves of $\mathrm{MC}$ and cisplatin, either alone or combination on healthy MCF-10A mammary cells and compared with breast cancer MCF-7 and MDAMB-231 cell lines. Cell viability was tested using $8 \mu \mathrm{g} / \mathrm{mL}$ and $80 \mu \mathrm{g} / \mathrm{mL}$ doses of MC extract, K-J and cisplatin individually or combined for 24 and 48 hours. Caspase-3- activity was measured in MCF-7 and MDA-MB-231 cells using established methods. The results revealed that MC extract and K-J had no effect on healthy MCF-10A cell viability as compared to cisplatin which induced dose and time-dependent cell death. Similarly, treatment of MCF-7 cells with cisplatin induced cell death at high concentration at both the time points, while MC extract and K-J only induce MCF-7 cell death at high dose after 48 hours only. During combination therapy, both doses of cisplatin enhanced MCF-7 cell death when combined with MC extract or K-J after 24 and 48 hours. In MDAMB-231 cells, the three drugs, either alone or combined, evoked significant cell death at both the doses and time points. All three drugs, at high dose, elicited significant increase in caspase-3- activity in MCF-7 and MDA-MB-231 cells as compared to untreated cells. The results revealed that either MC extract or K-J alone or combined with cisplatin, can elicit significant increase in cell death and caspase-3-activity in MCF-7 and MDA-MB-231cells as compared to untreated cells.
\end{abstract}

Keywords: Breast cancer, Cisplatin, Momordica charantia, Kuguacin-J, cell viability, caspase -3 . 


\section{Graphical Abstract}

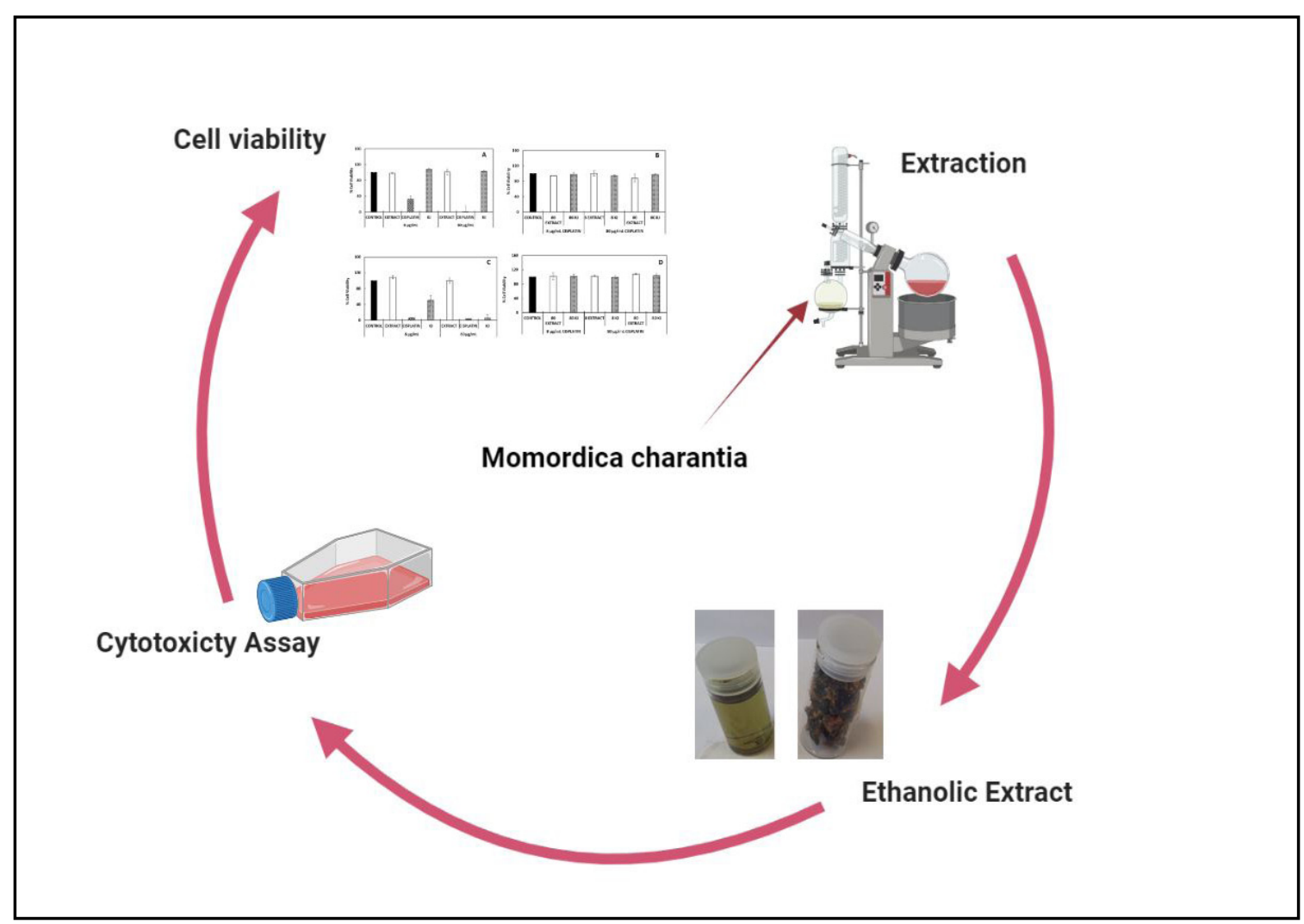

\section{Abbreviations:}

$\begin{array}{ll}\text { K-J } & \text { Kuguacin-J } \\ \text { BC } & \text { breast cancer } \\ \text { M. charantia } & \text { Momordica. charantia } \\ \text { MC } & \text { Momordica. charantia } \\ \text { HRT } & \text { hormone replacement therapy } \\ \text { BRCA1 and BRCA2 } & \text { breast cancer 1 and breast cancer } 2 \\ \text { FBS } & \text { Fetal bovine serum } \\ \text { ICPMS } & \text { Inductively coupled plasma mass spectrometry }\end{array}$

\section{Introduction}

Breast cancer $(\mathrm{BC})$ continues to be an increasing major public health problem worldwide and more so, it remains a significant scientific and communal challenge. Globally, breast cancer is the most frequently diagnosed cancer in women, with an estimated 19.3 million new cases and 10 million deaths annually worldwide making it the most common cause of female cancer death in both the developed and developing counties [1]. Breast cancer is the most common cancer in the UK, accounting for 54,722 $(15 \%)$ of all new cancer cases for women in 2017 ( $99 \%$ of breast cancer cases in the UK are in females and $1 \%$ are in males) [2]. For females, breast cancer European agestandardized incidence rates in the UK increased by $23 \%$ between 1993-1995 and 2015-2017. For males, breast cancer age-standard incidence rates in the UK remained stable between 1993-1995 and 2015-2017. Alarmingly, based on current projections, these figures are expected to triple by 2040 due to an ageing population, continued improvements in survival and of great concern from an economic point of view [3]. Recent research indicates that the annual burden of breast cancer to the UK economy is $£ 1.5 \mathrm{bn}$, while in the USA, it is estimated at \$19.7bn [4].

Despite substantial advances that have been made in the treatment of breast cancer, introduction of methods to predict which group of women are at elevated risk and prevention of the disease have been less successful. The incidence is rising in most countries and is projected to increase further over the next 20 years despite current efforts to prevent the disease [5-7]. 
BC is caused by many risk factors including obesity, alcohol consumption, inactivity, genetics, lowering age of menarche, late age of first pregnancy, fewer pregnancies, shorter or no periods of breast-feeding, a later menopause and hormone replacement therapy (HRT) and others [8]. Previous studies have shown that the impact of hereditary breast cancer has increased [9] with birth cohort effects seen for both breast cancer 1 (BRCA1) and breast cancer 2 (BRCA2) [10] and the data also suggest that both familial and non-familial risks have increased.

Atpresent, theprimary forms of treatment of cancerinclude surgery, radiation therapy, and systemic treatment, including chemotherapy, targeted therapy, hormonal therapy, and immunotherapy. Throughout the last halfcentury, cancer treatment has been characterized by highs and lows, due to the side effects, the ineffectiveness of treatment and the failed hope of complete remission and cure. Among the therapeutic arsenal, alongside surgery in the case of solid tumors, antitumor drugs and radiation have been the treatment of choice in many instances [11]. Among many chemotherapy drugs that are widely used for cancer, cisplatin is one of the most compelling ones. It was the first FDA-approved platinum compound for cancer treatment in 1978 [11]. Platinum responsiveness is high primarily, but many cancer patients will ultimately relapse with cisplatin-resistant disease. Hence, drug resistance has been observed in many patients who have relapsed from cisplatin treatment and more so the drug can also induce side effects [12].

As opposed to classic alkylating agents, cisplatin binds with DNA to form intra-strand crosslinks and adducts that cause changes in the conformation of the DNA and affect DNA replication. Other mechanisms of cisplatin cytotoxicity include mitochondrial damage, decreased ATPase activity, and altered cellular transport mechanisms. Published research studies have implicated DNA as a critical target for cisplatin cytotoxicity, the most revealing evidence being the hypersensitivity to cisplatin by both prokaryotic and eukaryotic cells deficient in DNA repair $[12,13]$

With the aforementioned cytotoxic side effects of this and other commercial antitumor drugs, it is of paramount importance to develop alternative therapies which can be applied either alone or in combination with other components to treat BC. Recently, immunotherapy has become an essential therapeutic alternative, and even nanotechnology has recently arrived on the scene, offering nanostructures as new therapeutic alternatives. However, side effects and remission persist [14].

One such alternative that has been used for many years to treat cancer and other diseases is plant-based extracts. Research has shown that the plant, Momordica charantia (M.charantia or MC) (Family: Cucurbitaceae) has been used as traditional medicine since ancient times for its various medicinal properties [15]. Several studies have conducted extensive research and published research and review papers on the extract of this plant and its components obtained from its fruits, seeds, leaves and stem [16-20].

The medicinal benefits of MC lie in the bioactive phytochemical components. These constitute chemicals which help to generate physiological effects on the human immune system, protecting it from various diseases. Of the many compounds that have been identified and isolated from MC, most of these falls under the groups of proteins and triterpenes. We have published a detailed review of MC and its isolated bioactive compounds [18], among one compound which have shown strong biological activities is cucurbitacins, a group of cucurbitane-type triterpenoids. Today, more than 50 triterpenoids have been isolated from $\mathrm{MC}$ including Kuguacin $\mathrm{J}(\mathrm{K}-\mathrm{J})$, a triterpenoid isolated from the leaves of Momordica charantia which have demonstrated apoptosis in androgen-dependent human prostate cancer $[20,21]$. The present study focused on the in vitro effects of an ethanol extract of the green fruit of $\mathrm{MC}, \mathrm{K}-\mathrm{J}$, a purified component of $\mathrm{MC}$ leaf extract and cisplatin, a commercial established anticancer drug, either alone or in combination on two different human breasts cancer cell lines, estrogen receptor ER-positive and progesterone receptor (PR)-positive MCF-7 and triple-negative MDBMB-231 cells and compared to healthy control MCF-10A breast cells. The rationale was to ascertain if a low dose of cisplatin combined with high doses of either the MC ethanol soluble extract or K-J can exert maximal effect in cell death without killing healthy cells in the body.

The main objective of this study was to find a natural product approach using plant-based medicine to treat TNBC. MDA-MB-231 is a highly aggressive, invasive and poorly differentiated triple-negative breast cancer (TNBC) cell line as it lacks ER and PR expression, as well as HER2 (human epidermal growth factor receptor 2) amplification were used in this study.

\section{Materials and Method}

\section{Materials and cell lines}

M. charantia was purchased fresh from local supermarket. Ethanol was purchased from Fisher Scientific. MCF-10A normal cell line (healthy) was maintained in Mammary Epithelial Cell Growth Medium and with passage 39-100. MCF-7 (breast adenocarcinoma cell lines) was maintained in Dulbecco's Modified Eagle's medium supplemented with $10 \%$ FBS and passage 40. Similarly, MDAMB-231 (Triple negative resistance breast cancer cell lines) were conducted with passage range from 40-56 in Dulbecco's Modified Eagle's medium (DMEM) supplemented with $10 \%$ Fetal bovine serum (FBS). MDAMB-231 line was 
purchased from Public Health, UK while all the media were purchased from Gibco (Thermo Fisher, Scientific, Waltham, MA, USA).

\section{Preparation of $M$. charantia plant ethanol extract}

The unripe green fruits of $M$. charantia were obtained from the local market and subsequently cleaned of internal tissues and cut into small pieces [22]. Approximately one kilogram of chopped green fruit was liquidized in $70 \%$ ethanol for 5-10 min using a blender at room temperature. The ethanol sample was poured into a $2 \mathrm{~L}$ bottle and capped. The bottle was then kept at room temperature for 6-8 weeks and mixed daily by shaking periodically. It was then filtered through Whatman filter paper (No: 4 Whatman, UK) to remove any residue. The filtered brown ethanol sample was then transferred to the 1000 $\mathrm{mL}$ round bottom rotating flask (Figure $1 \mathrm{~A}$ ). The flask was then connected to the Rota-evaporator machine through a clamp. The rotating flask was then heated by partial emersion in a hot water bath at a temperature of $40^{\circ} \mathrm{C}$. A typical $120 \mathrm{rpm}$ speed was used for the flask rotation. The rotary-evaporated sample was then scrapped using spatula and dried overnight in an oven at $43^{\circ} \mathrm{C}$. This crude ethanol soluble extract was stored at $2-5^{\circ} \mathrm{C}$ for further use (Figure 1B).

Measurement of cytotoxicity effect of MC alcoholsoluble extract, $\mathrm{K}-\mathrm{J}$ and cisplatin on the MCF-7 and MDAMB 231 breast cancer and MCF-10A healthy control cell lines using Presto-Blue Assay

An amount of $30 \mathrm{mg}$ of the crude alcohol-soluble extract of $M$. charantia was initially dissolved in $100 \mu$ DMSO by continuous stirring and with the brief use of a sonicator water bath. This was made up to $5 \mathrm{~mL}$ by adding $4.5 \mathrm{~mL}$ of the cell medium. The alcohol-soluble crude extract stock solution was filtered using $0.22 \mu \mathrm{m}$ sterile filters. These stock solutions were stored in a sealed tube at $2-5^{\circ} \mathrm{C}$ (fridge) until required. Once removed from the fridge $\left(2-5^{\circ} \mathrm{C}\right)$, the prepared alcohol-soluble extract of $M$. charantia solutions were gently warmed in a water bath at $37^{\circ} \mathrm{C}$ in order to ensure that the $\mathrm{MC}$ ethanol soluble extract was mixed complete in solution, before aliquoting into the concentrations of $8 \mu \mathrm{g} / \mathrm{mL}$ and $80 \mu \mathrm{g} / \mathrm{mL}$. Similarly, either K-J or cisplatin was weighed and dissolved in 100 $\mu \mathrm{L}$ DMSO and then diluted in the incubating medium at concentrations of $8 \mu \mathrm{l} / \mathrm{mL}$ and $80 \mu \mathrm{l} / \mathrm{mL}$. The two different concentrations of the MC alcohol soluble extract in cell medium were transferred in triplicate using a Gilson pipette to 96 well plates to give a final volume of $200 \mu \mathrm{l}$ to the treated cell wells. An equivalent volume of $200 \mu \mathrm{l}$ of the medium was added to the control (untreated) well with cells. For combination treatment, cisplatin (either 8 $\mu \mathrm{g} / \mathrm{mL}$ or $80 \mu \mathrm{g} / \mathrm{mL}$ ) was combined with either the alcohol soluble extract or $\mathrm{K}-\mathrm{J}$ using either $8 \mu \mathrm{l} / \mathrm{mL}$ or $80 \mu \mathrm{l} / \mathrm{mL}$. In this study, both time and dose-dependent experiments were performed either with each drug individually or during combination compared to control experiments without either drug for comparison. The time-dependent experiments were done initially over a period of 24 and 48 hours to ascertain the time that produced maximal cell death. Once the times of cell death were established, both time-and dose-dependent experiments were performed during the incubation period of 24 and 48 hours either alone or when combined. At the end of the treatment with either the MC alcohol soluble extract, K-J or cisplatin, the fluorescence was determined using Tecan-microtiter plate reader at excitation $570 \mathrm{~nm}$ and emission $610 \mathrm{~nm}$ [22]. Control experiments were also done using DMSO alone in the media which contained cells. The results showed that DMSO had no effect on cell death. The percentage cell viability (cell death) was calculated compared to the control subtracting the background reference employing the following equation:

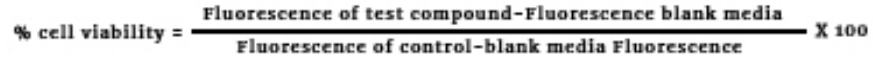

Measurements of caspase- 3 activity in untreated and treated MCF-7 and MDAMB-231 breast cancer cell lines with either the MC ethanol extract, $\mathrm{K}-\mathrm{J}$ or cisplatin

The two different breast cancer cells lines were incubated with $80 \mu \mathrm{g} / \mathrm{mL}$ of either crude water-soluble extract of $M$. charantia or K-J. The induced apoptosis cell suspension contained roughly $10^{7}$ cells. A sample of non-induced cells for a zero-time (control) also contained $10^{7}$ cells. The induced and non-induced cells were incubated for $48 \mathrm{~h}$ at $37^{\circ} \mathrm{C}$ in $5 \% \mathrm{CO}_{2}$ atmosphere. The induced cells and the control cells were transferred to $15 \mathrm{ml}$ centrifuge tube and centrifugation at $600 \times g$ for $5 \mathrm{~min}$ at $2-5^{\circ} \mathrm{C}$. The supernatant was removed by gentle aspiration for both induced and control cell suspensions. The cells were then pelleted and washed once with $1 \mathrm{ml}$ of phosphate buffer solution and centrifuged at $5000 \mathrm{rpm}$ for $5 \mathrm{~min}$ and the supernatant was completely removed by gentle aspiration. The centrifuged cell pellets were then treated with $1 \mathrm{X}$ lysis buffer at a concentration of $100 \mu \mathrm{l}$ per $10^{7}$ cells, and the cells were incubated on ice for 15-20 min. The lysed cells were centrifuged at 16,000 to $20,000 \times \mathrm{g}$ for 10 to $15 \mathrm{~min}$ at $2-5{ }^{\circ} \mathrm{C}$ and the supernatants were transferred to new $1 \mathrm{ml}$ tube and subsequently frozen in liquid nitrogen and stored in aliquots at $-70^{\circ} \mathrm{C}$ for further use (All the values were expressed as $\mu \mathrm{moL} / \mathrm{min} / \mathrm{mL}$ (Table 1 ).

\section{Analysis of M. charantia for some of its contents}

The green fruit of $M$. charantia was dried and pulverized into a powder and a known amount was dissolved in either deionized water or $70 \%$ ethanol for chemical analysis. These soluble samples were used to measure cation concentrations using ICPMS technique while antioxidant activity, vitamin-c, total protein, phenolic and antioxidant contents were measured by well- established biochemical methods [23, 24]. 


\section{Statistical Analysis}

All control and test data collected from the different experiments were analyzed using Student's $t$-test and ANOVA test via PRISM Graph-Pad software for comparison. Data obtained were expressed as mean \pm standard deviation (S.D). All experiments were performed in triplicate $(n=3)$. A value of $(p<0.05)$ was taken as a significant result.

\section{Results}

\section{Cytotoxicity of MC extract, K-J and cisplatin either alone or in combination}

The MCF10A human mammary epithelial cell line is a widely used in vitro model for studying normal breast cell function and transformation. Figure 2 shows light microscope morphological images of MCF-10A cells (A) without any drug treatment (control) and following treatment with $8 \mu \mathrm{g} / \mathrm{mL}$ of either (B) the alcohol soluble extract of $M$. charantia, (C) K-J or (D) cisplatin. These initial morphological studies have shown that the alcohol soluble extract and $\mathrm{K}-\mathrm{J}$, using $8 \mu \mathrm{g} / \mathrm{mL}$, had little or no effect on the viability of healthy MCF-10A cell line as compared to cisplatin which reduced cell viability causing cell death.

The data from three different experiments in Fig 2, using two different doses, were quantified and presented graphically as bar charts in Fig 3 for comparison. The results show that at low and high doses $(8 \mu \mathrm{g} / \mathrm{mL}$ and $80 \mu \mathrm{g} / \mathrm{mL}$ ), MC ethanol extract either alone or when combined with cisplatin had no significant $(\mathrm{p}>0.05)$ effect on the viability of healthy MCF-10A cell line at 24 and 48 hours of incubation (Fig 3A-D). On the other hand, $\mathrm{K}-\mathrm{J}$, a purified single anticancer compound from M.charantia, also had no effect on MCF-10A cell line at low dose of $8 \mathrm{ug} / \mathrm{mL}$ either alone or in combination with high and low doses of cisplatin after 24 hours of incubation (Fig 3A/B). When the dose of $\mathrm{K}-\mathrm{J}$ was increased to $80 \mathrm{ug} / \mathrm{mL}$, it killed MCF- 7 cells significantly $(\mathrm{P}<0.001)$ compared to untreated cells (Fig 3C). On the other hand, cisplatin, at both low and high doses $(8 \mu \mathrm{g} / \mathrm{mL}$ and 80 $\mu \mathrm{g} / \mathrm{mL})$, killed MCF-10A cells significantly $(\mathrm{p}<0.001)$ as compared to untreated (control) cells at both 24 and 48 hours of incubation (Fig 3A/C). Surprisingly, when K-J at a high dose was combined with either a low and a high dose of cisplatin, it had no significant ( $p>0.05)$ effect on cell viability compared to untreated (control) cells (Fig $2 \mathrm{~B} / \mathrm{D}$ ). These findings indicate that $\mathrm{MC}$ ethanol extract is safe to use in breast cancer therapy either alone or when combined with cisplatin. On the other hand, $\mathrm{K}-\mathrm{J}$ alone at a high dose seems to be less safe just like cisplatin since both can kill healthy breast cells.

Figure 4 shows the concentration-dependent cytotoxicity effect of either MC alcohol extract, K-J or cisplatin on MCF-7 breast cancer cells employing a separate (either 8 $\mu \mathrm{g} / \mathrm{mL}$ or high $80 \mu \mathrm{g} / \mathrm{mL}$ ) dose and combination treatment with either low or high dose $(8 \mu \mathrm{g} / \mathrm{mL}$ or high $80 \mu \mathrm{g} / \mathrm{mL})$ of cisplatin with MC ethanol extract or K-J for 24 hours and 48 hours of treatment. The results show that at a low dose, all three compounds had no effect on cell viability after 24 hours of treatment. However, when the cells were treated with a higher dose $(80 \mu \mathrm{g} / \mathrm{mL})$ of either of the three compounds for 24 hours, only cisplatin killed the cells significantly $(\mathrm{p}<0.005)$ compared to untreated (control) cells (Fig 3A). During combination treatment for 24 hours, employing a low dose $(8 \mu \mathrm{g} / \mathrm{mL})$ of cisplatin with a high dose $(80 \mu \mathrm{g} / \mathrm{mL})$ of either $\mathrm{MC}$ ethanol extract or K-J, cell viability reduced by around $25 \%$. However, when the dose of cisplatin was increased to $80 \mu \mathrm{g} / \mathrm{mL}$ and combined with $8 \mu \mathrm{g} / \mathrm{mL}$ of either the ethanol extract or K-J, cell death increased by about $25 \%$ after 24 hours of treatment. In contrast, when the dose of all the three compounds was increased to $80 \mu \mathrm{g} / \mathrm{mL}$, there was significant $(\mathrm{p}<0.001)$ increase in cell death (decreased cell viability) for both $\mathrm{K}-\mathrm{J}$ and MC ethanol extract after 24 hours which was more or less similar to the effect of cisplatin alone (Fig 2B).

Incubation of MCF-7 breast cancer cell line for 48 hours with $8 \mu \mathrm{g} / \mathrm{mL}$ with either compound individually resulted is a small, but significant $(\mathrm{p}<0.05)$ increase in cell death as compared to untreated (control) cells. When the concentration was increase to $80 \mu \mathrm{g} / \mathrm{mL}$, both the MC ethanol extract and cisplatin killed MCF-7 cells significantly $(\mathrm{p}<0.001)$ compared to untreated cells (Fig 3C). During combination treatments, cisplatin at either $8 \mu \mathrm{g} / \mathrm{mL}$ or $80 \mu \mathrm{g} / \mathrm{mL}$ was able to kill MCF-7 cells significantly $(\mathrm{p}<0.001)$ when incubated with either low $(8$ $\mu \mathrm{g} / \mathrm{mL})$ or high $(80 \mu \mathrm{g} / \mathrm{mL})$ of the $\mathrm{MC}$ ethanol extract or $\mathrm{K}-\mathrm{J}$ (Fig 3D). These finding support the hypothesis that combined application is a safer option for breast cancer therapy using a low dose of cisplatin with a high dose of MC ethanol extract or K-J for 48 hours of treatment.

Fig 5 shows the dose-dependent cytotoxicity effect of either MC ethanol extract, $\mathrm{K}-\mathrm{J}$ or cisplatin on MDA-MB231-triple negative cell line employing individual and combined doses for comparison following 24 hours and 48 hours of treatments. Compared to MCF- 7 breast cancer cells, the results presented in Fig 5A-D clearly show that either MC ethanol extract, K-J or cisplatin were highly effective, either alone or in combination, in killing MDAMB-231-triple negative breast cancer cells significantly $(p<0.001)$ compared to untreated (control) cells at all doses and treatment times employed in this study. These results demonstrated that either the $M C$ alcohol soluble extract, $\mathrm{K}-\mathrm{J}$ or cisplatin either alone or in combination at a low dose of $8 \mu \mathrm{g} / \mathrm{mL}$ was as effective as a high dose $80 \mu \mathrm{g} /$ $\mathrm{mL}$ in killing MDA-MB-231 breast cancer cells, making the MC ethanol extract a very safe treatment option for triple negative breast cancer. 


\section{Measurement of caspase -3 activity}

There are a number of subcellular, cellular, molecular and structural mechanisms whereby anti-cancer drugs can induce cell death including apoptosis, autophagy, necrosis, microtubule disassembling, DNA damage, mitochondrial cytochrome release and calcium over-loading as well as others. In some cases, more than one processes occur, and however it is well known that apoptosis is the dominant type involving the formation of multi-protein complexes that provide the molecular scaffolding for the activation of the initiator caspases including caspase -8 (extrinsic pathway), caspase -9 (intrinsic pathway) and caspase -3 (executioner caspase caspase-3 pathway) [25, 26].

Since the MC ethanol extract, K-J and cisplatin can induce cell death of both MCF-7 and MDA-MB-231triple negative cell lines, it was relevant to investigate the cellular mechanism(s) or pathway(s) involved in cell death. Caspase-3 activity was investigated on using caspase-3 calorimetric kit reading the absorbance using Tecan plate reader. Caspase activity was observed after treating the cells with a dose of $80 \mu \mathrm{g} / \mathrm{mL}$ for 48 hours. The amount of protein released during the assay was quantified and used to determine the caspase activity. The results are presented in figure 6 and they show that MC ethanol extract, $\mathrm{K}-\mathrm{J}$ and cisplatin can elicit significant $(\mathrm{p}<0.05)$ increase (two-fold) in caspase-3 release (enhanced activity) in both MCF-7 and MDAMB-231 cell lines as compared to control after 48 hours of treatment. Surprisingly, there was significant difference $(\mathrm{p}<0.05)$ between the activity of caspase-3 produced by MC ethanol extract, $\mathrm{K}-\mathrm{J}$ and cisplatin. Typically, in both MDAMB-231 and MCF-7cell lines the MC ethanol extract, K-J and cisplatin increased caspase -3 activity by 82,75 and $76 \%$, respectively, indicating that all three agents are inducing cancer cell death through the activation of the caspase-3 pathway.

\section{Chemical contents of $M$. charantia}

Following chemical analysis, the results show that the fruit is rich in proteins $(2.86+0.07 \%)$, vitamin $\mathrm{C}$ $(125+1.75 \mathrm{mg} / 100 \mathrm{~g})$, carotenoid $(1.09+0.06 \mathrm{mg} / 100 \mathrm{~g})$, phenolic content $(2.42+0.25 \mathrm{mg} / 100 \mathrm{~g})$, anti-oxidant activity dry weight $(44.5+2.46 \%)$, including the presence of caffeic (221 ng/g) and celuic acid (623.6 ng/g) and a number of cations including sodium $(7.76+0.51 \mathrm{mg} / \mathrm{g})$, potassium $(0.667+0.044 \mathrm{mg} / \mathrm{g})$, calcium 28.95+2.21 $\mathrm{mg} / \mathrm{g})$, magnesium $(0.443+0.0028 \mathrm{mg} / \mathrm{g})$, manganese $(0.42+0.03 \mathrm{mg} / \mathrm{g})$, copper $(0.26+0.031 \mathrm{mg} / \mathrm{g})$ and zinc $(0.99+0.03 \mathrm{mg} / \mathrm{g})$. Among the cations, the fruit had significantly $(\mathrm{p}<0.05)$ more sodium and calcium compared to the other cations present.

\section{Discussion}

Globally, breast cancer (BC) is the most common cancer in women with the most recent published statistics indicating 19.3 million new cases in 2021, second only to lung cancer, which corresponds to $11.6 \%$ of all new cancer cases. Research has shown that breast cancer was responsible for 10 million deaths in 2021, representing $6.6 \%$ of cancer deaths [1].

Sadly, it is estimated that these values will continue to increase as it is estimated that by 2050, the yearly incidence of $\mathrm{BC}$ will reach around 3.2 million [27]. BC is caused by many risk factors including age, obesity, radiation, genetic disposition, family history of the disease which may link to inherited genes, excess alcohol intake, lack of exercise, hormone replacement therapy (HRT), personal history of $\mathrm{BC}$, race/ethnicity, menstrual, breastfeeding and pregnancy history, dense breast, exposure to environmental factors, chemicals, drugs and many others $[28,29]$. BC can be easily prevented by eating a balanced diet, exercising regularly and reducing alcohol intake and avoid smoking. Moreover, knowledge of the disease and regular mammogram tests can help in early diagnosis and treatment of the disease successfully resulting in a better quality of life for the victim [28].

Some forms of BC are easy to treat, whereas others are very difficult to treat, and occurrence is very prevalent. Currently, the primary forms of treatments include surgery followed by radiotherapy, chemotherapy and others such as palliative care for living well [11, 12]. Most commercial drugs are given, depending on the type of the $\mathrm{BC}$ that is being treated, where the cancer is located in the breast and types of breast cells affected [18,28-31]. Moreover, most of the commercial chemotherapeutic agents are not safe since they can kill normal healthy cells in the body especially at high doses [32]. As such, it is of paramount importance to look for new and safe forms of therapy. This is where the current research project comes in as an alternative form of safe treatment for BC using natural plant-based medicine either alone or in combination with a low dose of a commercial therapeutic anti-cancer agent combined with a high dose of the natural medicine or extract $[18,21]$.

Natureisarich source of differenttypes of naturalmedicinal and phytochemical products and for years scientists have been utilizing plant-based extracts and medicine to treat different types of cancers [21, 32]. Second, if single drug therapy is unable to treat the cancer, then it is important to employ combined therapy. Momordica charantia (MC) or bitter melon is a well-known plant which has been used for thousands of years as a natural medicine to treat several diseases including diabetes and cancer inflicting mankind [15, 33]. In two previous studies, we investigated the beneficial anticancer effects of a water-soluble extract 
of $\mathrm{MC}$ and $\alpha, \beta$ momorcharin, an isolated compound of $\mathrm{MC}$, on several different cancer cell lines including 1321N1, Gos-3, U87-MG, Sk Mel, Corl -23, Weri Rb-1[16, 17]. In light of these two previous studies, the current investigation was designed to ascertain a cost-effective and safe approach to treat BC using an ethanol soluble extract from $M$. charantia and compare with the effect of $\mathrm{K}-\mathrm{J}$, an isolated anticancer compound from the leaves of $M$. charantia and cisplatin, a commercial anticancer drug. The rationale of this study was to find a safe dose of $\mathrm{BC}$ ethanol soluble extract or $\mathrm{K}-\mathrm{J}$ either alone or in combination with a low dose cisplatin to treat $\mathrm{BC}$ without killing healthy cells and where possible, the mechanism involved in BC cell death. The discussion will now focus on the main findings of this study and their relevance in BC therapy, especially for people in low-income countries in the world where they have to pay for healthcare [34].

The results of this study have demonstrated that the active anticancer ingredient(s) from the green succulent fruit in $M$. charantia is ethanol soluble and several studies have employed the same procedure in preparing the extracts which are highly efficacious in treating other diseases successfully including diabetes and cancer [15, $19,35]$. In the present study, both low and high doses of the MC ethanol extract and K-J had no effect on the viability of healthy MCF-10A breast cell lines compared to cisplatin which killed over $60 \%$ of the cells after 24 hours of treatment. However, during 48 hours of treatment both doses of MC ethanol extract seemed to enhance cell viability slightly compared to $\mathrm{K}-\mathrm{J}$ and cisplatin which killed MCF-10A cells with cisplatin being more toxic at both low and high doses compared to $\mathrm{K}-\mathrm{J}$ at the higher concentration. Surprisingly, when cisplatin was combined with either $\mathrm{MC}$ ethanol extract or K-J, employing both doses, they had little or no significant effect on MCF-10A cell at both 24 and 48 hours of treatment. The results have clearly demonstrated that MC ethanol extract is safe to use in breast cancer therapy either alone or when combined with cisplatin since it does not kill the healthy cells even during 48 hours of treatment and rather reduce the toxic effects of cisplatin. In contrast, K-J alone, especially at high dose and longer treatment time, can kill the healthy cells. Interestingly, both MC ethanol extract and K-J seem to exert a protecting effect on the healthy cells against the adverse effect of cisplatin at both low and high doses at either 24 or 48 hours of treatment (Fig 3B/D). The current results are in agreement with two previous studies which revealed that that the water-soluble extract of MC had no cytotoxic effect on healthy cell lines $[16,17]$.

MCF-7 is a human breast cancer cell line was isolated in 1970 from a Caucasian woman with metastasis and it has estrogen, progesterone and glucocorticoid receptors and as such it is a well-established in vitro as a cell line model to study the effects of drugs on cell viability [36]. The results of this study have shown that either the MC ethanol extract or K-J had no significant effect at a low dose on MCF-7 cell viability at 24 hours of treatment. However, at a higher dose of $80 \mu \mathrm{g} / \mathrm{mL}$ and 24 hours of treatment, MC ethanol extract seemed to enhance MCF7 cell proliferation compared to $\mathrm{K}-\mathrm{J}$ which reduced cell viability slightly (Fig 4A). When a high dose of cisplatin was combined with a high dose of either MC ethanol extract or $\mathrm{K}-\mathrm{J}$, they elicited more than $80 \%$ of cell death compared to untreated (control) cell at 24 hours (Fig 4B). This effect was more or less the same as with cisplatin alone. However, during 48 hours of treatment with a low dose, either MC ethanol extract, K-J or cisplatin reduced cell viability by about $25 \%$. At a high dose and during 48 hours of treatment, $\mathrm{K}-\mathrm{J}$ evoked only a small effect on cell death compared to the MC ethanol which induced about $50 \%$ of cell and cisplatin which killed more than $90 \%$ of the cancer cells (Fig 4C). Interestingly, when either a low or a high dose of cisplatin was combined with a high dose of either MC ethanol extract or K-J for 48 hours, they evoked significant increases in MCF-7 cell death. Together, the main results from this part of the study revealed that a low dose of cisplatin combined with a high dose of either MC ethanol extract or K-J could elicit a synergistic effect on MCF -7 cell death after 48 hours of treatment. As such, the finding supports the hypothesis that combined application is a safer option for breast cancer therapy using a low dose of cisplatin and a high dose of MC ethanol extract or K-J. These results are in total agreement with related studies which show that bitter melon extract or juice alone can reduced the viability of $\mathrm{MCF}-7$ and other cancer cell lines especially at a longer duration of treatment $[19,37]$.

Triple negative breast cancer (TNBC) represents almost $10-20 \%$ of all breast cancers globally. This is due to the absence of estrogen and progesterone receptors and HER2 proteins. TNBC cells do not respond to hormone therapy and as such, new and novel medicines are required to prevent their growth and subsequent death, but at the same time leaving healthy cells intact [38].

The results presented in figure 5 are highly significant and demonstrated that either the MC ethanol soluble extract, $\mathrm{K}-\mathrm{J}$ or cisplatin either alone or in combination at low and high doses could kill MDAMB-231 (TNBC) cells by more than $90 \%$ after both 24 and 48 hours of treatment, making the MC ethanol extract and possible $\mathrm{K}-\mathrm{J}$ at low concentration as very safe options in TNBC therapy. The present results are in agreement with a related study which employed $2 \%$ of bitter melon fruit juice $(\mathrm{v} / \mathrm{v})$ alone on both MCF-7 and MDAMB-231using 12, 24 and 48 hours of treatment $[19,37,39]$. In addition to individual application of either MC ethanol extract, K-J or cisplatin like other studies, the present study also investigated combined therapy employing cisplatin with either MC ethanol extract or $\mathrm{K}-\mathrm{J}$.

It is now known that different anticancer drugs exert their killing effect via different cellular, subcellular and molecular mechanisms involving autophagy, 
cellular calcium overloading, necrosis, microtubule disassembling, DNA damage, cell cycle arrest, suppression of c-Met signalling, mitochondrial cytochrome release and apoptosis [25, 26]. Programmed cell death or apoptosis occurs naturally in cells and many drugs kill cancer cells by this process. However, the underlying mechanisms of the growth inhibitory effects of M charantia extract and $\mathrm{K}-\mathrm{J}$ in breast cancer cell remains poorly understood. In some cases, more than one processes occur, however, it is known that apoptosis is the dominant type involving the formation of multi-protein complexes that provide the molecular scaffolding for the activation of the initiator caspases including caspase -8 (extrinsic pathway), caspase-9 (intrinsic pathway) and caspase-3 (executioner caspase caspase -3 pathway $[25,26,40,41]$. The results presented in figure 6 show that in both MDAMB-231 and MCF-7 cell lines, MC ethanol extract, K-J and cisplatin were able to increase caspase -3 activity by $82 \%, 75 \%$ and $76 \%$, respectively, indicating that all three agents are inducing breast cancer cell death through the activation of caspase-3 pathway. In two previous studies [17, 22], we had shown that a water soluble of $M$. charantia and $\alpha$, $\beta$ momorcharin, an isolated compound from bitter melon, were able to kill several cancer cell lines via apoptosis and cellular calcium overloading $[16,17]$. It is tempting to suggest that other intracellular signally pathways may be involved in MDAMB-231 and MCF-7 cell death but this warrants further experiments.

The results of this study have revealed that $M$. charantia is rich in a number of cations, especially sodium and calcium, proteins, phenols, antioxidants and other compounds. Other studies have reported more than 250 bioactive compounds with medicinal and nutritious characteristics in $M$. charantia [41-45]. The question which now arises is: how MC ethanol extract and $\mathrm{K}-\mathrm{J}$ exerts their lethal effect when applied extracellularly to cells in vitro. Control experiments have shown that the dose of DMSO employed to dissolve either $\mathrm{K}-\mathrm{J}$, cisplatin or the MC extract had no effect on all three cell lines employed in this study. It is possible that either $\mathrm{K}-\mathrm{J}$ or the active agent (s) in MC extract is lipid soluble and as such they can enter the cells very easily to activate different signaling pathways to elicit cell death via apoptosis $[19,21]$. Currently, there is no evidence of receptor -mediated effect of extract of $M$. charantia or its isolated compounds.

\section{Conclusion}

The results of this study have clearly demonstrated that MC alcohol soluble extract had no effect on healthy human mammary epithelial MCF-10A cells as compared to cisplatin at all concentrations and $\mathrm{K}-\mathrm{J}$ at a high dose. Moreover, either MC ethanol soluble extract, $\mathrm{K}-\mathrm{J}$ or cisplatin either alone or in combination, using different doses, can evoke significant decrease in the viability of MCF-7 and MDA-MB-231 triple negative cancer cells in vitro. The cytotoxic effects of the three compounds were more pronounced in MDAMB-231 triple negative cancer cells as compared to MCF-7 cells. Moreover, all three compounds can exert their lethal anti-cancer effect on the cancer cells via damage of cell mitochondria body resulting in an elevation in the cellular mediator, caspase-3. It is concluded that it is safe to employ MC ethanol extract as a cytotoxic agent in breast cancer therapy especially in moderate concentration either alone or when combined with a low dose of a commercial anticancer drug such as cisplatin in order to enhance the efficacy of the drugs. Future studies would involve in vivo studies in breast cancer pre-clinical model to confirm these results.

\section{Conflict of interest}

The authors have claimed no competing interests in this study.

\section{Author contributions}

EC, KJ and JS constructed the concept of whole study and they were recipients of the research grant. $\mathrm{CH}$, RS and AAA performed investigation at UCLan. KS validated the data and carried on statistical analysis and reviewed the manuscript. $\mathrm{CH}$, JS, and RS wrote the original manuscript. All authors edited and revised the manuscript and approved it for publication.

\section{Financial and competing interests' disclosure}

The authors have no relevant affiliations or financial involvement with any organization or entity with a financial interest in or financial conflict with the subject matter or materials discussed in the manuscript. Moreover, no writing assistance was employed in the production of this manuscript. The work was supported by a research grant by the World Bank to the University of Guyana (EC/KG) and the University of Central Lancashire (UClan) (JS) and it had the relevant ethical clearance from both Universities.

\section{Data availability statement}

All data generated or analysed during this study are included in this published article.

\section{References}

1. Sung H, Ferlay J, Siegel RL, Laversanne M, Soerjomataram I, Jemal A, Bray F. Global cancer statistics 2020: GLOBOCAN estimates of incidence and mortality worldwide for 36 cancers in 185 countries. CA: a cancer journal for clinicians. 
2021 May;71(3):209-49.

2. 2. UK C R (2017) Breast cancer incidence (invasive) statistics. [Accessed on 2020 23-11];Available from: http ://www.cancerresearchuk.org/cancerinfo/cancerstats/types/breast/incidence/\#trends.

3. Maddams J, Utley M, Møller H. Projections of cancer prevalence in the United Kingdom, 2010-2040. British journal of cancer. 2012 Sep;107(7):1195-202.

4. Luengo-Fernandez R, Leal J, Gray A, Sullivan R. Economic burden of cancer across the European Union: a population-based cost analysis. The lancet oncology. 2013 Nov 1;14(12):1165-74.

5. Eccles SA, Aboagye EO, Ali S, Anderson AS, Armes J, Berditchevski F, Blaydes JP, Brennan K, Brown NJ, Bryant HE, Bundred NJ. Critical research gaps and translational priorities for the successful prevention and treatment of breast cancer. Breast Cancer Research. 2013 Oct;15(5):1-37.

6. Rahib L, Smith BD, Aizenberg R, Rosenzweig AB, Fleshman JM, Matrisian LM. Projecting cancer incidence and deaths to 2030: the unexpected burden of thyroid, liver, and pancreas cancers in the United States. Cancer research. 2014 Jun 1;74(11):2913-21.

7. Arnold M, Karim-Kos HE, Coebergh JW, Byrnes G, Antilla A, Ferlay J, Renehan AG, Forman $\mathrm{D}$, Soerjomataram I. Recent trends in incidence of five common cancers in 26 European countries since 1988: Analysis of the European Cancer Observatory. European journal of cancer. 2015 Jun 1;51(9):1164-87.

8. Colditz GA, Bohlke K. Priorities for the primary prevention of breast cancer. CA: a cancer journal for clinicians. 2014 May;64(3):186-94.

9. Tryggvadottir L, Sigvaldason H, Olafsdottir GH, Jonasson JG, Jonsson T, Tulinius H, Eyfjörd JE. Population-based study of changing breast cancer risk in Icelandic BRCA2 mutation carriers, 19202000. Journal of the National Cancer Institute. 2006 Jan 18;98(2):116-22.

10. Evans DG, Shenton A, Woodward E, Lalloo F, Howell A, Maher ER. Penetrance estimates for
BRCA 1 and BRCA 2 based on genetic testing in a Clinical Cancer Genetics service setting: risks of breast/ovarian cancer quoted should reflect the cancer burden in the family. BMC cancer. 2008 Dec;8(1):1-9.

11. Dasari S, Tchounwou PB. Cisplatin in cancer therapy: molecular mechanisms of action. European journal of pharmacology. 2014 Oct 5;740:364-78.

12. Dasari S, Tchounwou PB. Cisplatin in cancer therapy: molecular mechanisms of action. European journal of pharmacology. 2014 Oct 5;740:364-78.

13. Weber GF. DNA Damaging Drugs. Molecular Therapies of Cancer. 2014 Dec 8:9-112.

14. Jabir NR, Tabrez S, Ashraf GM, Shakil S, Damanhouri GA, Kamal MA. Nanotechnology-based approaches in anticancer research. International journal of nanomedicine. 2012;7:4391.

15. Joseph B, Jini D. Antidiabetic effects of Momordica charantia (bitter melon) and its medicinal potency. Asian Pacific Journal of Tropical Disease. 2013 Apr 1;3(2):93-102.

16. Manoharan G, Cummings E, Singh J. Effects of crude water-soluble extract of Momordica charantia on viability, caspase activity, cytochrome-c release and on cytosolic calcium levels in different cancer cell lines. Cancer Cell \& Microenvironment. 2014;1.

17. Manoharan G, Jaiswal SR, Singh J. Effect of $\alpha, \beta$ momorcharin on viability, caspase activity, cytochrome $c$ release and on cytosolic calcium levels in different cancer cell lines. Molecular and cellular biochemistry. 2014 Mar;388(1):233-40.

18. Singh RM, Cummings E, Patel M, Jeeboo K, Singh J. Anti-cancer properties of bioactive compounds isolated from Momordica charantia: A mini review. Adv Med Plant Res. 2016;4(3):83-93.

19. Muhammad N, Steele R, Isbell TS, Philips N, Ray RB. Bitter melon extract inhibits breast cancer growth in preclinical model by inducing autophagic cell death. Oncotarget. 2017 Sep 12;8(39):66226.

20. Bao B, Chen YG, Zhang L, Xu YL, Wang X, Liu J, $\mathrm{Qu}$ W. Momordica charantia (Bitter Melon) redu- 
ces obesity-associated macrophage and mast cell infiltration as well as inflammatory cytokine expression in adipose tissues. PLoS One. 2013 Dec 17;8(12):e84075.

21. Dandawate PR, Subramaniam D, Padhye SB, Anant S. Bitter melon: a panacea for inflammation and cancer. Chinese journal of natural medicines. 2016 Feb 1;14(2):81-100.

22. Pitchakarn P, Ohnuma S, Pintha K, Pompimon W, Ambudkar SV, Limtrakul P. Kuguacin J isolated from Momordica charantia leaves inhibits P-glycoprotein (ABCB1)-mediated multidrug resistance. The Journal of nutritional biochemistry. 2012 Jan 1;23(1):76-84.

23. Bernardo MA, Silva ML, Santos E, Moncada MM, Brito J, Proença L, Singh J, de Mesquita MF. Effect of cinnamon tea on postprandial glucose concentration. Journal of diabetes research. $2015 \mathrm{Jul}$ $14 ; 2015$.

24. Bradford MM. A rapid and sensitive method for the quantitation of microgram quantities of protein utilizing the principle of protein-dye binding. Analytical biochemistry. 1976 May 7;72(1-2):24854.

25. Diaz LF, Chiong M, Quest AF, Lavandero S, Stutzin A. Mechanisms of cell death: molecular insights and therapeutic perspectives. Cell Death \& Differentiation. 2005 Nov;12(11):1449-56.

26. McIlwain DR, Berger T, Mak TW. Caspase functions in cell death and disease. Cold Spring Harbor Perspectives in Biology. 2015 Apr;7(4).

27. Torre LA, Bray F, Siegel RL, Ferlay J, Lortet-Tieulent J, Jemal A. Global cancer statistics, 2012. CA: a cancer journal for clinicians. 2015 Mar;65(2):87108.

28. Xydakis AM, Sakkas EG, Mastorakos G. Hormone replacement therapy in breast cancer survivors. Annals of the New York Academy of Sciences. 2006 Dec;1092(1):349-60.

29. Waks AG, Winer EP. Breast cancer treatment. Jama. 2019 Jan 22;321(3):316-

30. Tong CW, Wu M, Cho W, To KK. Recent advances in the treatment of breast cancer. Frontiers in oncology. 2018 Jun 14;8:227.

31. Society A C (2020) Targeted therapy for breast cancer [Accessed on 2020 23/11]; Available from:https://www.cancer.org/cancer/breast-cancer/treatment/targeted-therapy-for-breast-cancer.html.

32. Fang EF, Froetscher L, Scheibye-Knudsen M, Bohr VA, Wong JH, Ng TB. Emerging antitumor activities of the bitter melon (Momordica charantia). Current Protein and Peptide Science. 2019 Mar 1;20(3):296-301.

33. Alam MA, Uddin R, Subhan N, Rahman MM, Jain P, Reza HM. Beneficial role of bitter melon supplementation in obesity and related complications in metabolic syndrome. Journal of lipids. 2015 Jan 1;2015.

34. Limtrakul P, Pitchakarn P, Suzuki S. Kuguacin J, a Triterpenoid from Momordica charantia Linn: A Comprehensive Review of Anticarcinogenic Properties. Carcinogenesis. 2013 Jan 23;275.

35. Richmond RA, Vuong QV, Scarlett CJ. Cytotoxic Effect of Bitter Melon (Momordica charantia L.) Ethanol Extract and Its Fractions on Pancreatic Cancer Cells in vitro. Exploratory Research and Hypothesis in Medicine. 2017 Dec 22;2(4):139-49.

36. Comşa Ş, Cimpean AM, Raica M. The story of MCF-7 breast cancer cell line: 40 years of experience in research. Anticancer research. 2015 Jun 1;35(6):3147-54.

37. Ray RB, Raychoudhuri A, Steele R, Nerurkar P. Bitter melon (Momordica charantia) extract inhibits breast cancer cell proliferation by modulating cell cycle regulatory genes and promotes apoptosis. Cancer Research. 2010 Mar 1;70(5):1925-31.

38. Cancer Org B (2020) Triple-Negative Breast Cancer. [Acessed on 2020 23-11]; Available from: https://www.breastcancer.org/symptoms/diagnosis/ trip_neg.

39. Bai LY, Chiu CF, Chu PC, Lin WY, Chiu SJ, Weng JR. A triterpenoid from wild bitter gourd inhibits breast cancer cells. Scientific reports. 2016 Mar $1 ; 6(1): 1-0$. 
40. Los M, Walczak H. Caspases: their role in cell death and cell survival. Landes Bioscience; 2002.

41. Ummi R, Teti E, Endang S. Bioactive compound and nutritious characteristic of bitter melon fruit (Momordica charantia L.). Russian Journal of Agricultural and Socio-Economic Sciences. $2018 ; 79(7)$.

42. Raina K, Kumar D, Agarwal R. Promise of bitter melon (Momordica charantia) bioactives in cancer prevention and therapy. InSeminars in cancer biology 2016 Oct 1 (Vol. 40, pp. 116-129). Academic Press.
43. Dia VP, Krishnan HB. BG-4, a novel anticancer peptide from bitter gourd (Momordica charantia), promotes apoptosis in human colon cancer cells. Scientific reports. 2016 Sep 15;6(1):1-2.

44. Bortolotti M, Mercatelli D, Polito L. Momordica charantia, a nutraceutical approach for inflammatory related diseases. Frontiers in pharmacology. 2019 May 8;10:486.

45. Sur S, Ray RB. Bitter Melon (Momordica Charantia), a Nutraceutical Approach for Cancer Prevention and Therapy. Cancers. 2020 Aug;12(8):2064.

\begin{tabular}{|c|c|c|c|c|c|}
\hline Test Samples & Cell lysate & $\begin{array}{c}\text { Caspase-3 } \\
5 \mu \mathrm{g} / \mathrm{ml}\end{array}$ & 1x Assay buffer & $\begin{array}{c}\text { Caspase-3 } \\
\text { inhibitor Ac- } \\
\text { DEVD-CHO } \\
200 \mu \mathrm{M} \\
\end{array}$ & $\begin{array}{c}\text { Caspase-3 } \\
\text { substrate Ac- } \\
\text { DEVD-pNA } \\
2 \mathrm{mM} \\
\end{array}$ \\
\hline Reagent blank & ----- & ----- & $90 \mu \mathrm{l}$ & ----- & $10 \mu \mathrm{l}$ \\
\hline Non-induced cells & $5 \mu \mathrm{l}$ & ----- & $85 \mu \mathrm{l}$ & ----- & $10 \mu \mathrm{l}$ \\
\hline $\begin{array}{c}\text { Non-induced cells+ } \\
\text { inhibitor }\end{array}$ & $5 \mu l$ & ----- & $75 \mu \mathrm{l}$ & $10 \mu \mathrm{l}$ & $10 \mu \mathrm{l}$ \\
\hline Induced cells & $5 \mu \mathrm{l}$ & ----- & $85 \mu \mathrm{l}$ & ----- & $10 \mu \mathrm{l}$ \\
\hline $\begin{array}{c}\text { Induced cells + } \\
\text { inhibitor }\end{array}$ & $5 \mu \mathrm{l}$ & ----- & & $10 \mu \mathrm{l}$ & $10 \mu \mathrm{l}$ \\
\hline $\begin{array}{c}\text { Caspase-3 } \\
\text { positive control }\end{array}$ & ----- & $5 \mu \mathrm{l}$ & $85 \mu \mathrm{l}$ & ----- & $10 \mu \mathrm{l}$ \\
\hline $\begin{array}{l}\text { Caspase }-3 \text { positive } \\
\text { control }+ \text { inhibitor }\end{array}$ & ----- & $5 \mu \mathrm{l}$ & $75 \mu \mathrm{l}$ & $10 \mu \mathrm{l}$ & $10 \mu \mathrm{l}$ \\
\hline
\end{tabular}

Table 1: Protocol of caspase-3 assay reaction scheme for 96 well plate micro-assay method 
Figures

(A)

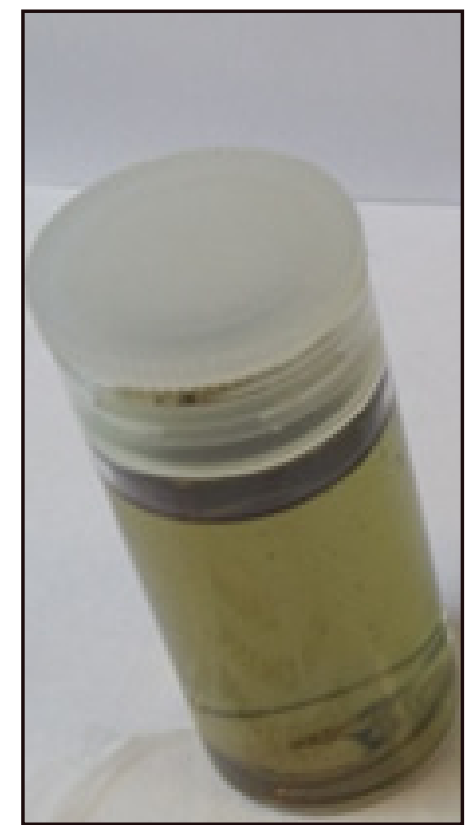

(B)

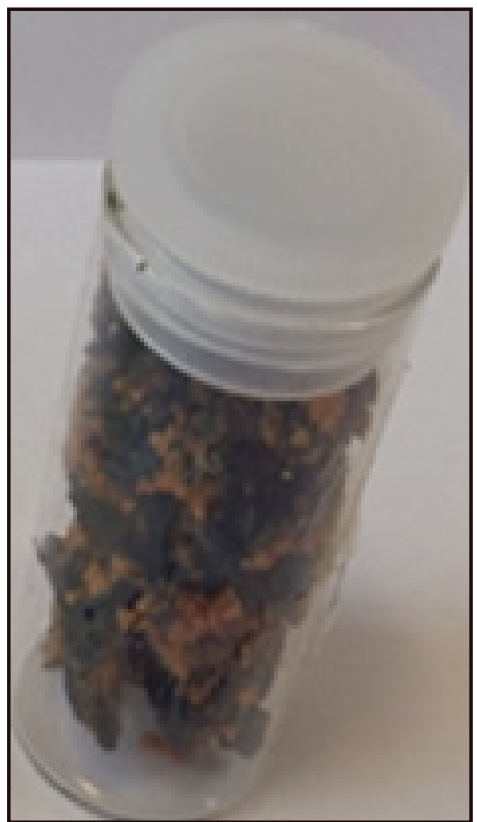

Figure 1: (A) dark green alcohol extract solution and (B) M. charantia alcoholic solid extract.
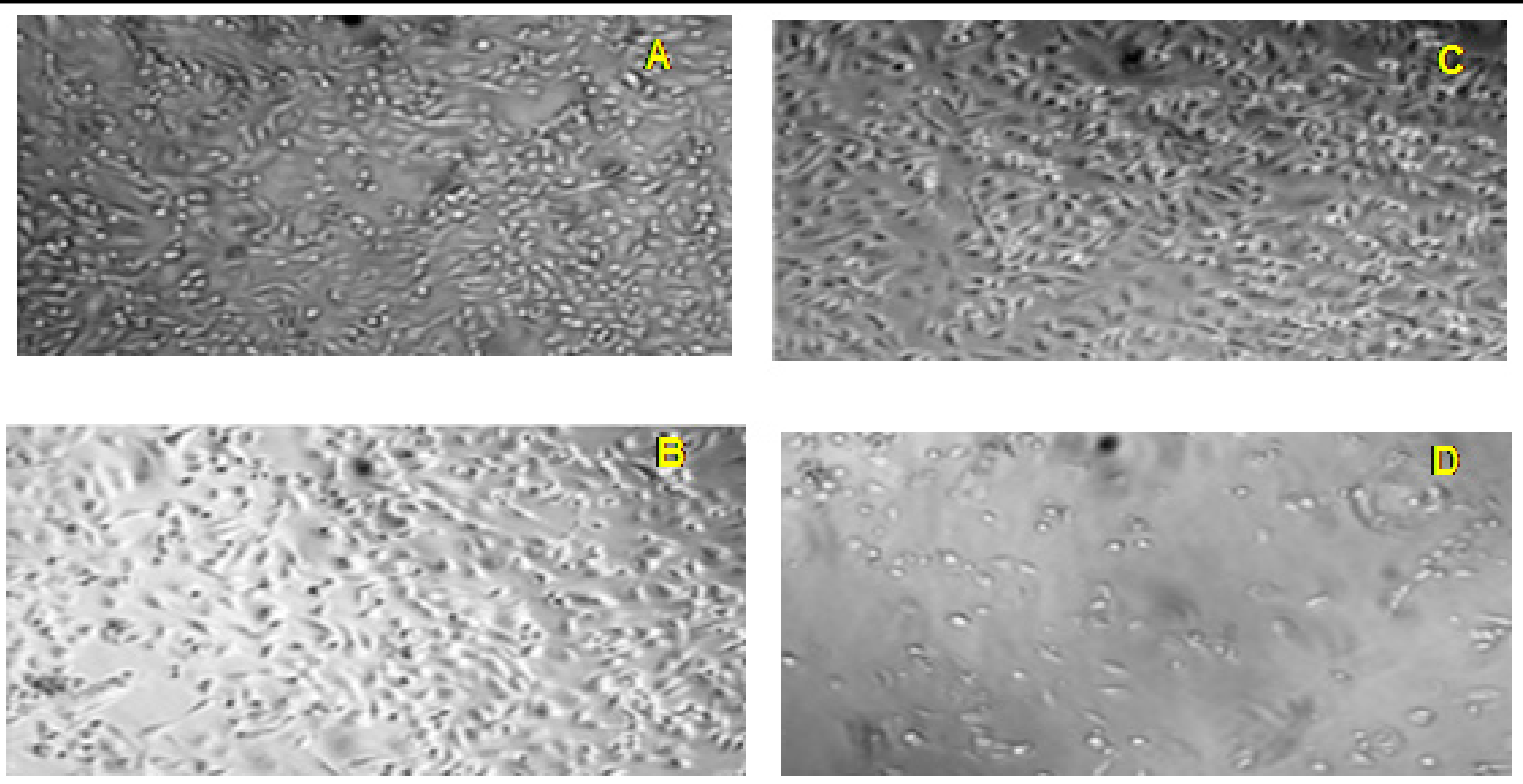

Figure 2: Light microscope images of MCF-10A cells: (A) without treatment (control) and following treatment with $8 \mathrm{ug} / \mathrm{mL}$ of either (B) the alcohol soluble M. charantia extract, (C) K-J or (D) cisplatin. These images are typical of at least 3 different experiments. 


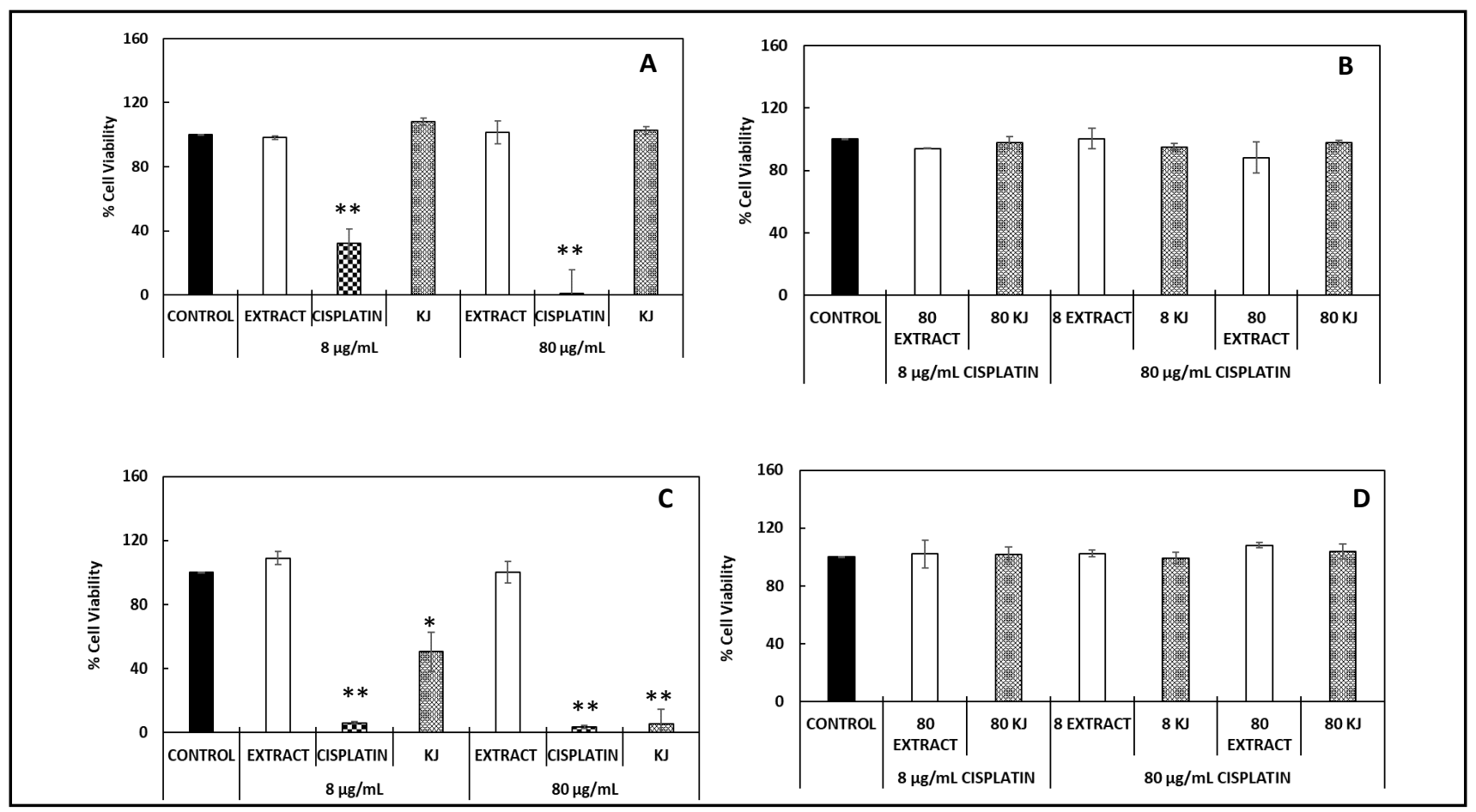

Figure 3: Dose-dependent cytotoxicity effect of the MC ethanol extract, K-J and cisplatin on healthy MCF-10A cell lines compared to untreated (control) cells for comparison. Fig 3A- each dose separately and Fig 3B- combined doses for 24 hours; Fig 3C- each dose separately and Fig 3D- combined doses for 48 hours. Data are mean $\pm S D,(n=3)$; ${ }^{*} \mathrm{p}<0.05, * * \mathrm{p}<\mathbf{0 . 0 0 1}$ for cisplatin in A and $\mathrm{C}$ compared to untreated control and for $\mathrm{K}-\mathrm{J}$ in $\mathrm{C}$ compared to untreated (control) cells.

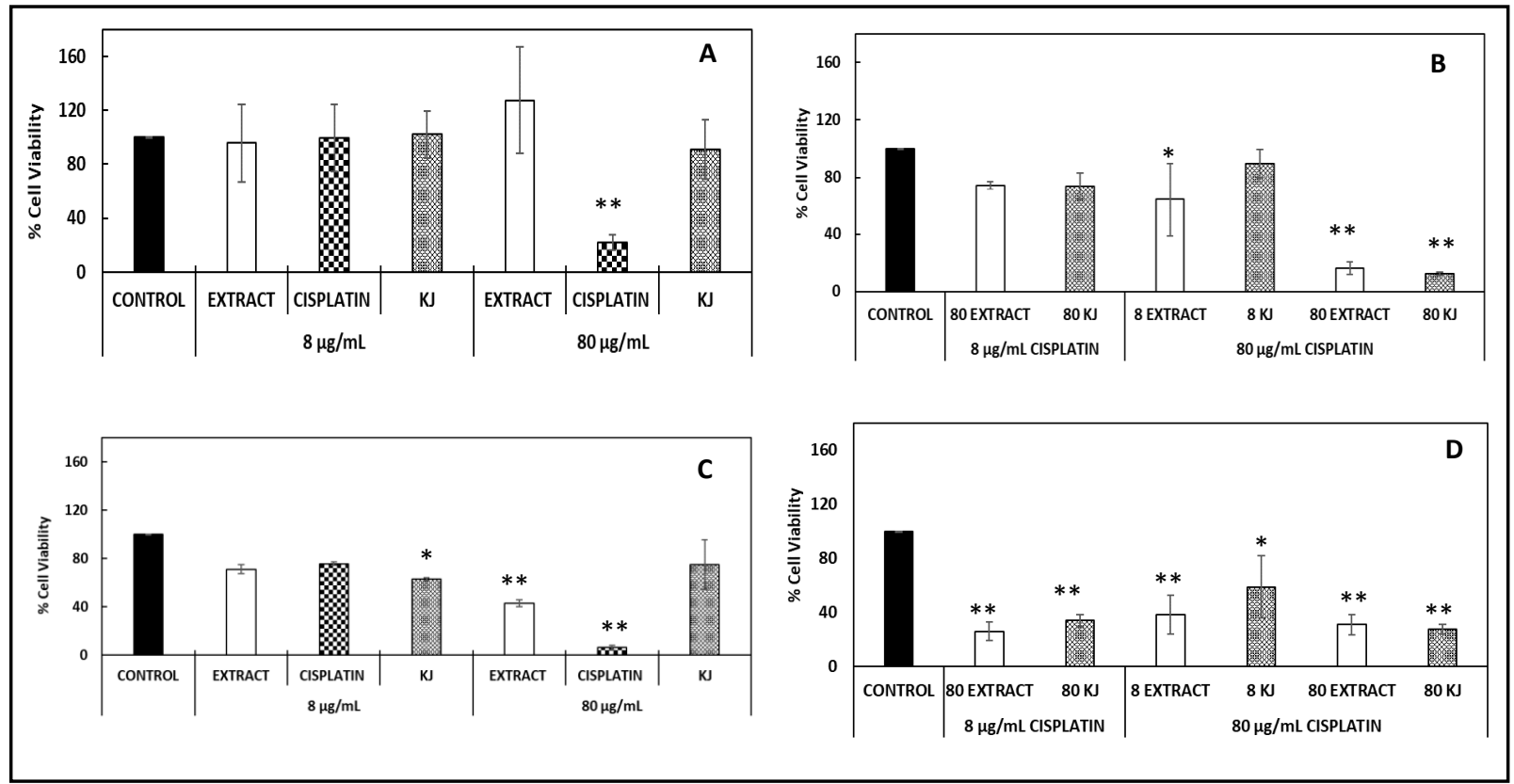

Figure 4: Dose -dependent cytotoxicity effect of the MC ethanol extract, K-J and cisplatin on MCF-7 breast cancer cells compared to untreated (control) cells for comparison. Fig 4A- each dose separately and Fig $4 \mathrm{~B}$ - combined doses for 24 hours; Fig 4C- each dose separately and Fig 4D- combined doses for 48 hours. Data are mean $\pm \mathrm{SD},(\mathrm{n}=3)$; $* * \mathrm{p}<0.001 * \mathrm{p}<0.05$ for MC ethanol extract, $\mathrm{K}-\mathrm{J}$ and cisplatin in $\mathrm{A}, \mathrm{C}$ and $\mathrm{D}$ compared to untreated (control) cells and in $B$ for $(80 \mathrm{ug} / \mathrm{mL}) \mathrm{MC}$ ethanol extract or $\mathrm{K}-\mathrm{J}$ combined with $(80 \mathrm{ug} / \mathrm{mL})$ cisplatin compared to untreated control. 


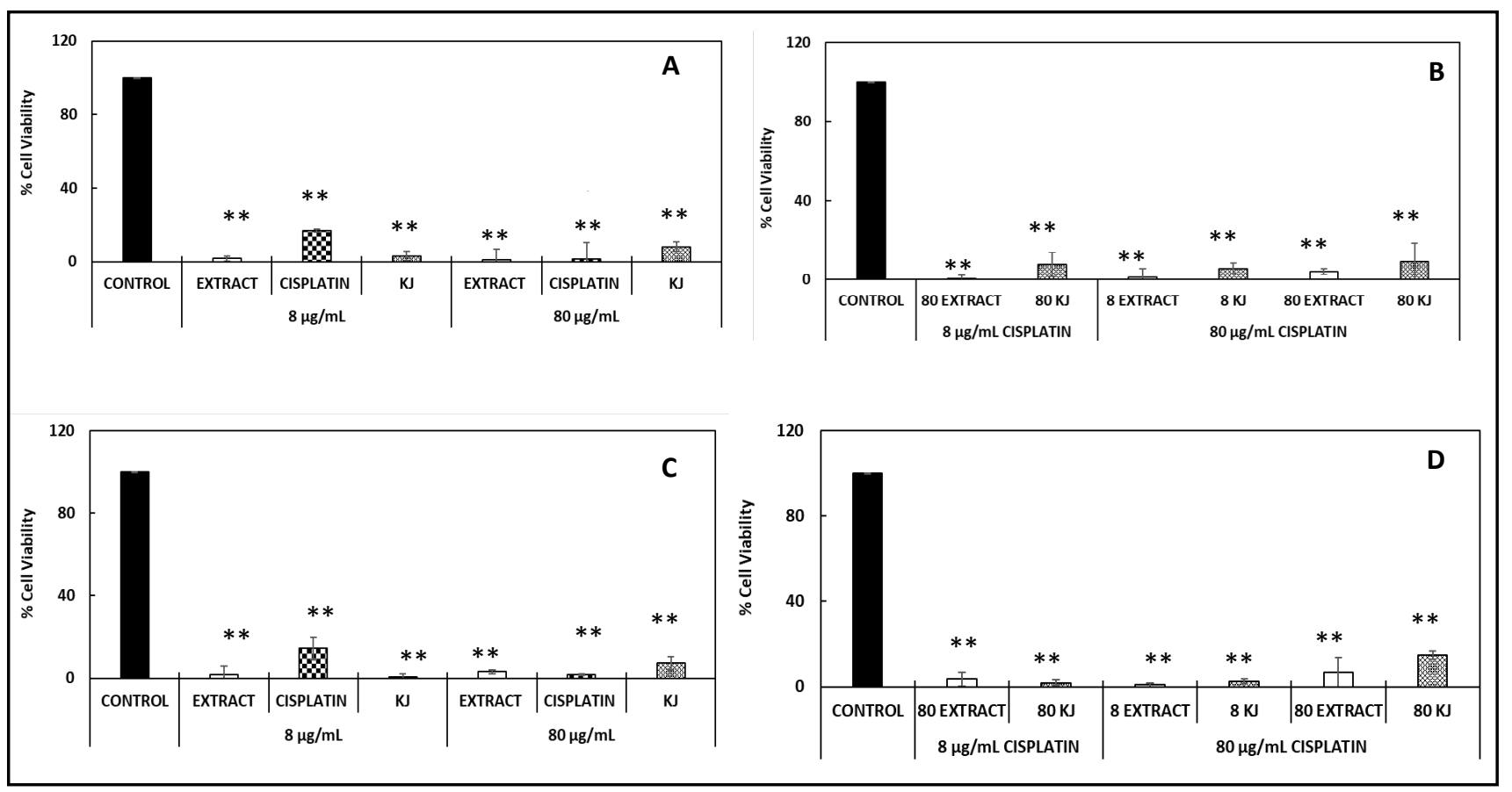

Figure 5: Dose -dependent cytotoxicity effect of the MC ethanol extract, K-J and cisplatin on MDAMB-231 triple negative breast cancer cell compared to untreated (control) cells for comparison. Fig $5 \mathrm{~A}-$ each dose separately and Fig $5 \mathrm{~B}$ - combined doses for $24 \mathrm{~h}$; Fig $5 \mathrm{C}$ - each dose separately and Fig $5 \mathrm{D}$ - combined doses for 48 hours. Data are mean \pm $\mathrm{SD},(\mathrm{n}=3)$; ** $\mathrm{p}<0.001$ for MC ethanol extract, $\mathrm{K}-\mathrm{J}$ and cisplatin in $\mathrm{A}, \mathrm{B}, \mathrm{C}$ and D compared to untreated (control) cells.

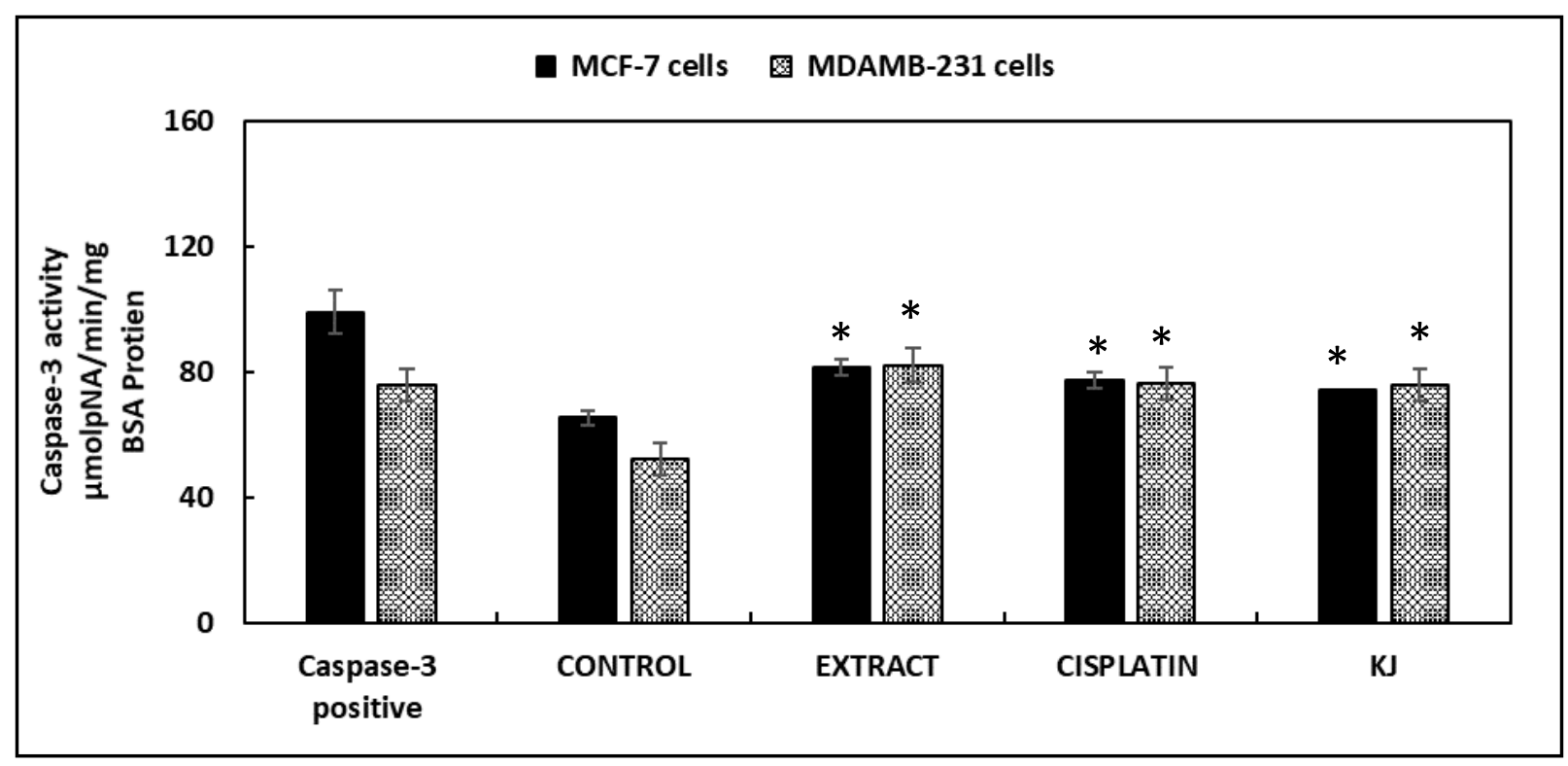

Figure 6: Bar charts showing the caspase-3 activity (elevation) on MCF-7 and MDAMB-231 cell lines following treatment with either MC ethanol extract, $\mathrm{K}-\mathrm{J}$, or cisplatin. Data are mean $\pm \mathrm{SD}, \mathrm{n}=3 ; * \mathrm{p}<0.05$ for test compared to control. 